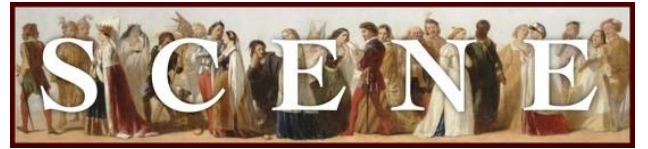

\title{
Slippery in Seattle: The Winter's Tale
}

\section{by Sean Henry. Written on 2016-12-27. Published in 2017 Issue 2.}

For the production: The Winter's Tale (2016, Seattle Shakespeare Company, USA). See production details at the end of the review.

The Seattle Shakespeare Company opened its TWenty-SiXTh SEASON IN SePtember 2016 with The Winter's Tale, directed by Sheila Daniels at the Seattle Repertory's Leo K. Theatre-an intimate space that suited this relatively spare production. Soothing recordings of classical guitar played before the performance, perhaps signaling to the audience that what followed would be a traditional production of the play. And, indeed, apart from two interpolated entrances by the entire cast (at the opening and at the beginning of Act 4) and a spectral appearance by Hermione behind Antigonus during his soliloquy before his death by bear, the production was straightforward and unfussy. With minimal sets (a collection of rectangular pillars that served in turn as the architecture of the Sicilian court and the trees of Bohemia) and little stage business to distract from Shakespeare's words, such straightforwardness served to emphasize how the play divides in two parts that resolve each other, moving from Sicilian winter to Bohemian spring.

Daniels incorporated a few interpolations, however. The play opened with the cast entering the darkened stage, carrying lanterns and chanting part of Pablo Neruda's posthumous "Winter Garden" in turn:

\section{I am a book of snow, a spacious hand, an open meadow, a circle that waits, I belong to the earth and its winter.}

During this opening, a spotlight focused on an hourglass downstage left, later presented by Polixenes to Leontes when he initially seeks to leave Sicily. Although the intended effect of emphasizing the seasonal themes of the play was clear, I am not sure how successful the opening or the other interpolations were in drawing out what is already in Shakespeare. Indeed, these moments seem in tension with the trust the production otherwise showed for the text of the play. 
Leontes dominates the first three acts, and in Darragh Kennan's Leontes, the production has its strongest performance. Kennan is comfortable with delivering verse with clarity and emotion. He presents the king's descent into jealous madness without subtext, offering no psychological explanation for the roots of the royal suspicions beyond what the audience observes on stage, but his performance does not suffer as a result. While Leontes watches Hermione and Polixenes musing "Too hot, too hot," all but Kennan freeze in tableau, allowing the actor to move across the stage to look more closely, gesture at the pair, and address the audience. Meanwhile, a protracted, dull, headache-inducing note drones over the sound system at each such aside, raising the tension of the scene. Kennan interacts with the audience, sitting on the edge of the stage and pointing at "many a man" who little knows (pointing elsewhere) that "Sir Smile, his neighbor" has fished his pond, thus interjecting a sinister merriness to Leontes. One quibble might be Kennan's tendency to rush over the sexual double-entendres embedded in Leontes' observations, robbing the crescendo of "nothings" in 1.2 of its vitriolic obscenity, for example.

Polixenes is something of a thankless (if not dull) role, but Reginald Andre Jackson plays him with dignity. Actors of color play the Bohemian royal family in a casting choice that evokes through white Leontes' rage what might be called a reversal of Othello's jealousy and the complicated anxieties of race-not only in the recollection of the Moor's tragedy, but also in a play produced in a country during the fall of 2016 undergoing a presidential election fraught with questions of race relations. The production does not allude to contemporary politics beyond this casting choice, but they are inescapable.

Sheila Daniels also seems to draw upon Hamlet in Leontes' costuming. Where the Sicilians begin the play dressed in simple stage versions of Renaissance costume (the women in green and red; the men in black and neutral colors), the king appears during the worst of his jealousy without a doublet or shoes, his shirt and hose unkempt, embodying Renaissance descriptions of madmen. Later, during the trial, while Leontes reappears in doublet, carrying a drawn sword, Hermione's costume echoes these mad clothes: a simple white shift. Brenda Joyner as Hermione is at her best in this scene, embodying honesty and power in ways suggesting she is more than a match for her husband. She stands upstage on a platform during her trial, a lone figure in white, shining. In contrast, Amy Thone's Paulina did not suggest the strength necessary to deal with Leontes; moreover, Thone initially seemed uncomfortable speaking verse. She physically attacks Leontes, then spoons with him when the realization of what he has done crushes him to the stage.

To modern audiences, The Winter's Tale can appear unbalanced, with pastoral Bohemia appearing less interesting and more ineffectual than the story of Hermione and Leontes. And, indeed, the Seattle Shakespeare Company's production wanders a bit during its time in 
Bohemia. Modern lack of interest in the pastoral mode, combined with the obscurity of Perdita and Polixenes' talk of flower-breeding, made audience attention palpably flag. Costume and stage-setting signal the differences in geography and mood: the columns of the Sicilian court become trees of a Bohemian forest, and (perhaps taking "Bohemian" too literally) the characters dress in sandals, sky-blue Nehru jackets, and beads (exiled Camillo looks for all the world like a bespectacled chartered accountant who has dropped out and joined an ashram). The production includes two pastoral dances: the first reminiscent of swing dancing, while the second, incorporating bull masks and fertility rituals that seem intended to suggest (what my companion called) "a certain pagan 'witchiness' about the whole thing," emphasized the production's focus on seasonal change and rebirth. Again, I wonder whether the symbolic emphasis was overdone.

Just as Leontes dominates the first part of the play, so Autolycus dominates the latter. Some productions are known to double the parts. Here, M. J. Sieber is a knowing, carnal Autolycus, winking at Seattle and its Bohemian foibles. Sieber enters as Autolycus from the audience, bearded, strumming a ukulele and drinking a Pabst Blue Ribbon beer (reminiscent of presentday hipster culture), though dressed like a Grunge musician from Seattle's early 1990s.

"Welcome to Act 4," he smiles when he reaches the stage, and passes his empty beer can to someone in the front row: "Recycle that-we're in Bohemia." If Darragh Kennan's Leontes seems unaware of all the lewdness he speaks, then Sieber's Autolycus makes up for it. He sizes up the young shepherd with a hungry eye as prey for both his thieving and homoerotic gaze. He punctuates his selling song,

\section{Masks for faces and for noses; \\ Pins and poking-sticks of steel, \\ What maids lack from head to heel,}

by brandishing condoms ("masks...for noses") and a vibrator ("poking-sticks of steel") at his would-be customers. Later, when disguised as a courtier, Autolycus' beard becomes a fashionable Bohemian "man-bun" through a quick switch. Kennan and Sieber are the highlights of this production.

When the Sicilians arrive again on stage, they are dressed in Victorian mourning clothes. The conclusion of the production had all the textual power The Winter's Tale carries for emotional resolution, however costumed. I have not seen a production get the wish-fulfillment implicit in the play wrong--that yearning for those people and places, states and things, we have lost and can never in this life get back. The play works. The resolution is not just one of spring-like rebirth promised by the love of the next generation, but a restoration of the nostalgic past-a 
return to hope before pain, jealousy, or loss. The Seattle Shakespeare Company gets this hope, and much else, right, to judge by the tears on many faces as the audience left the theater.

\section{Production Details}

\section{General}

Title

Year

Theater Company

Theaters

Start Date

End Date

\section{Cast}

\begin{tabular}{|c|c|}
\hline KING LEONTES & DARRAGH KENNAN \\
\hline PRINCE MAMILLIUS & FINN KENNAN \\
\hline LORD CAMILLO & GALEN JOSEPH OSIER \\
\hline LORD ANTIGONUS & GEORGE MOUNT \\
\hline LORD Cleomines & SPENCER HAMP \\
\hline King Polixenes & REGINALD ANDRE JACKSON \\
\hline PRINCE FLORIZEL & Rudy Roushdi \\
\hline LORD ARCHIDAMUS & M.J. SIEBER \\
\hline OLD SHEPHERD & MARK FULLERTON \\
\hline YOUNG SHEPERD & SPENCER HAMP \\
\hline Autolycus & M.J. SIEBER \\
\hline MARINER & DENNY LE \\
\hline JAILER & MARK FULLERTON \\
\hline QuEEN HeRmione & BRENDA JOYNER \\
\hline PRINCESS PERDITA & JASMINE JEAN SMITH \\
\hline PAULINA & AMY THONE \\
\hline LADY EMILIA & JONELLE JORDAN \\
\hline MOPSA & JONELLE JORDAN \\
\hline DORCAS & RACHEL GUYER-MAFUnE \\
\hline LORD & MARK Fullerton \\
\hline LORD & DENNY LE \\
\hline LORD & Rudy Roushdi \\
\hline LADY & RACHEL GUYER-MAFUNE \\
\hline LADY & JASMINE JEAN SMITH \\
\hline
\end{tabular}

The Winter's Tale

2016

Seattle Shakespeare Company

Leo K. Theatre, Seattle Repertory Theatre (USA)

2016-09-07

2016-10-02 
Shepherd DenNy Le

\section{Creatives}

DIRECTOR

ASSISTANT DiRECTOR

Costume Designer

Master Stage CARPENTER

SET Designer

Lighting DesigneR

SOUND DESIGNER

Master Audio Engineer

COMPSER

CHOREOGRAPHER

TECHINAL DIRECTOR

Advisory TECHNICAL DiRECTOR

Stage Manager

Assistant Stage MANAgER

WARDROBE MASTER

MASTER ELECTRICIAN

Properties Designer
SHELIA DANIELS

Meme Garcia

KELLY MCDONALD

CASE Lutes

TOMmer Peterson

REED NAKAYAMA

HARRY TODD JAMIESON

MARK KRIDA

RAFAEL MOLINA

MARC KENISON

ADRIAN DELAHUNT

CRAIG WOLLAM

MiRANDA C. PRATT

EMMA PIHL

Cindy SABye

JEDIDIAH ROE

ROBIN MACARTNEY 